\title{
Research on Constructing College English Ecological Classroom from Perspective of Internet Information
}

\author{
Yang Yang \\ School of Foreign Languages \\ Jinlin Institute of Chemical Technology \\ Jilin, China
}

\begin{abstract}
The advancement of internet informatization has had a great impact on the traditional college English classroom, and it is very urgent to build a new college English ecological classroom. Based on the theory system of ecolinguistics, this paper analyzes ecological imbalance of traditional college English classroom, puts forward some practical countermeasures, and carries out preliminary exploration in teaching.
\end{abstract}

Keywords-ecological English classroom; ecolinguistics; imformation technology; Internet

\section{INTRODUCTION}

Faced with the reality of reform under the background of internet informatization, the traditional college English ecosystem has changed greatly. The rapid development of information technology in China, the increasing popularity of WIFI in smart phones, the increasing coverage and diversity of information factors have formed a synergy which impact on education obviously. As the first line of English education, college English education must be influenced by this great trend. The changes of teaching elements and teaching links have taken place in traditional classroom as follows: (1) teaching resources, (2) teaching method, (3) study method, (4) teaching evaluation.

The basic structure of college English class can be simplified as classroom ecological subject and classroom ecological environment. Classroom ecological subject can be refined for teachers and students. Classroom ecological environment can be refined into teaching materials, teaching method, teaching environment, teacher-students relationship, rules and regulations. These ecological factors in classroom ecosystem interact and depend on each other, make up an ecological community. The use of modern information technology will inevitably break the original balance of ecological factors. At the same time, the original ecological factors will put forward new requirements. If other ecological factors don't keep pace with information technology factors, the original smooth ecological college English classroom environment will lose its balance.

\section{ANALYSIS}

\section{A. Imbalance Between Teachers and Information Technology Factors}

1) Understanding of teacher's role in class: Some teachers did change the understanding of the teacher's role along with the process of college English teaching informatization. They still insist on teacher-centered classroom instruction. The orientation of teachers' role tend to be traditional. They didn't adjust their role in classroom timely with the rapid information technology development. They didn't realize the importance of students knowledge exploration and knowledge building. Teachers should play the role of guides and supporters in teaching. Personalized teaching, interactive teaching, task-based teaching, and research-oriented teaching are the scientific and effective teaching models accord with the ecology of college English class.

2) Concept of knowledge and practice: Some teachers have a clear understanding of the profound impact that Internet information factors have brought into the traditional college English classroom. They are willing to use information technology to inject vitality into traditional college English classes, but there is a serious deviation in teaching behavior. They believe that the use of multimedia courseware is the embodiment of information teaching. Their over-reliance on multimedia courseware weakened the teachers' subjective initiative and flexibility. Some teachers' knowledge of Internet-based learning is too simple. They think that assigning some learning tasks on the network platform is the major way of network teaching. They neglect the following teaching sessions such as counseling, evaluation, diagnosis and feedback. Some teachers, due to early knowledge structure, age and other personal reasons, resist the Internet information technology. They are reluctant to devote their time and energy to learning complex Internet-based teaching system. 
TABLE I.

CURRENT COMBINATION OF ICT AND COLLEGE ENGLISH EDUCATION

\begin{tabular}{|l|c|c|c|}
\hline \multicolumn{1}{|c|}{ Research items } & $\begin{array}{c}\text { Agree } \\
(\mathbf{\%})\end{array}$ & $\begin{array}{c}\text { Neutral } \\
(\mathbf{\%})\end{array}$ & $\begin{array}{c}\text { Disagree } \\
(\mathbf{\%})\end{array}$ \\
\hline $\begin{array}{l}\text { Teachers' basic ICT level } \\
\text { and primary combination }\end{array}$ & 63.51 & 24.57 & 11.92 \\
\hline $\begin{array}{l}\text { Teachers' high ICT level } \\
\text { and good combination }\end{array}$ & 17.74 & 31.5 & 50.76 \\
\hline $\begin{array}{l}\text { Teachers' negative attitude } \\
\text { to combination }\end{array}$ & 50.4 & 49.6 \\
\hline
\end{tabular}

\section{B. Imbalance Between Students and Information} Technology Factors

1) Learning concepts lag: Due to many years of examination - oriented teaching, most students depend on teachers' classroom instruction for foreign language learning. They are dissatisfied with the way teachers applied in the information context, and they think the teaching method is time-consuming and inefficient. At the same time, information network learning requires students to spend a lot of time to complete online learning. Under high-density curriculum and homework pressure, many students prefer to reduce the time spent on English learning through Internet.

2) Lack of information literacy: The current college students are a generation growing up with the rapid development of internet information technology. They are sensitive to information technology and have certain information literacy. But their information literacy mainly reflects on the technical level, not civilized level, they lack the knowledge of the characteristics of information learning. Their horizon of using information technology to English learning has not been widened. Faced with the complex network learning resources, they can't make a proper option. Some college students lack the ability of self-regulation and spend a lot of time on online games and entertainment programs.

\section{Practical CONTERMEASURES}

Reconstructing the college English classroom ecology in the context of informatization can follow the principles of ecological, systematical and humanly effectiveness. By playing the leading role, controlling the influence of limited factor and constructing of ecological classroom environment, the structure and function of English ecological classroom can be reconstructed.

\section{A. From the Aspect of Teachers}

College English teachers should pay more attention to the idea of teaching innovation. They should improve their information literacy, adjust the role of classroom identity, and develop equal and harmonious relationship between teachers and students. They should change the traditional control and acceptance teaching methods into open and diversified teaching method.

\section{B. From the Aspect of Students}

According to the students' learning level, learning needs and learning style, the English teachers should apply classification training system and multi-level curriculum system to enable students' personalized development. They are required to improve the diversified evaluation system. The evaluation should include process evaluation and interactive evaluation. The teachers should regard the evaluation as the ultimate goal by applying the multiple coexisted elements in English classroom, and then demonstrate the ecological functions of the diversified evaluation system.

\section{From the Aspect of Teaching Environemnt}

College English teachers should construct a multidimensional interactive classroom learning environment and devote themselves to the construction of three-dimensional teaching resources. Make full use of the rich internet learning resources, school network learning platform, and intelligent mobile terminal generalization. It is necessary to develop the network course system of school nature. Use the "flip classroom" teaching method to make the dull and inefficient college English classroom vivid. Finally, the harmonious, efficient and friendly English ecological classroom environment will be created.

\section{CONCLUSION}

The research applies the cross-disciplinary perspective and relevant theories of ecolinguistics. The paper aims at investigating a series of imbalance arouses by the interference of the modern information into the college English classroom. And then put forward the practical strategies.

\section{A. Research Method}

Literature reviewing is the major research method. By this means, the practical problems in college English class are analyzed. Collate the previous theoretical research results, through their own thinking and practice, some solutions to the problems has been brought up.

\section{B. Research Contents}

Through the process of raising problems, analyzing problems and solving problems, this study mainly focus on speculative discussion. Although there are some positivist summaries based on practical teaching behavior, a lot of content is still in the concept stage. Some views, with a clear tendency of personal empiricism, need to be tested in practice.

Due to the limitations of the author's educational background, the understanding of the interdisciplinary theory of ecolinguistics is not deep enough. As for many problems, the study only stays on the surface, not in-depth excavation. In the process of investigation and analysis of problems, there is a lack of collection and collation of scientific data For college English classroom ecology research, qualitative and quantitative research should be combined. As the research goes deeper, it is necessary to study the impact of 
some certain factors in the ecological system and then put the result into practice.

\section{ACKNOWLEDGMENT}

I am very grateful to Professor Ni Xiujie for her helpful comments and constant support in this research. My sincere thanks go to the students who have always been active in my English class. I would also like to thank my team members who have given me some constructive comments on the paper.

\section{REFERENCES}

[1] Garrison, D. R \& N.D. Vaughan. Blended Learning in Higher Education: Principles and Guidelines [M]. San Francisco: JosseyBass, 2008.

[2] Leather, J.\&Dam, J.V. (2003). Ecology of Language Acquisition. Dordrecht: Kluwer Academic Publishers.

[3] Owston,R, York, D. \& S. Murtha. Student perceptions and achievement in a university blended learning strategic initiative [J]. The Internet and Higher Education, 2013(8).

[4] Paloff, R. \&K. Pratt. Building Learning Communities in Cyberspace [M]. San Francisco: Jossey-Bass 1999.

[5] So, H . J. \& T. A. Brush. Student perceptions of collaborative learning, social presence and satisfaction in a blended learning environment: Relationships and critical factors [J]. Computers \& Education, 2008(1).

[6] Wattenberg, W. W. (1977). The Ecology of Classroom Behavior. Theory into Practice, 4,256-261.

[7] Whalen, C.K et al. (1979). A Social Ecology of Hyperactive Boys: Medication Effects in Structured Classroom Environments. Journal of Applied Behavior Analysis, 1, 65-81. 